\title{
Rationale for restructuring and regulation of a 'low priced' public utility: a case study of Eskom in South Africa
}

\author{
Anton Eberhard and Msafiri Mtepa ${ }^{1}$ \\ Professor and Director, Infrastructure Industries Reform and Regulation \\ Management Programme, Graduate School of Business, University of Cape \\ Town, South Africa
}

International Journal of Regulation and Governance 3(2): 77-102

\begin{abstract}
Eskom in South Africa provides an interesting case study to test the prevailing orthodoxy on electricity market reform. Eskom is the seventh largest electricity utility in the world. It is a publicly owned, vertically integrated monopoly, with the cheapest prices globally. Is there any rationale for independent regulation of Eskom or for embarking on a reform of the South African electricity market?

The paper gives a snapshot view that Eskom's current prices can be misleading. Low current prices do not necessarily mean that Eskom is operationally or allocatively efficient. Eskom's electricity prices are low primarily because Eskom did not have to invest in new generation plant for many years. Much of the debt it incurred during the large expansion programme in the 1970s and 1980s has been amortized. Eskom's short-run marginal costs are also low, primarily because its primary energy costs are well below international levels. Lower costs have also been maintained though improved labour productivity and technical performance-although contradictory trends are observed which make it hard to benchmark Eskom's operational efficiency against international best practice.

Eskom's historical investment record has been poor. The analysis in this paper reveals the significant misallocation of capital by Eskom's decision-makers and the massively wasteful overcapacity in the generation plant. The impact on prices has been profound.
\end{abstract}


Eskom has not always had competitive prices. In real terms, they were nearly double the current levels in the late 1970s and 1980s and will have to rise in the future as capacity runs out and new investments have to be made in generation. Furthermore, the longterm price trend reveals that current electricity prices, in real terms, are no lower than they were in the early 1950s and early 1970s. The question then has to be asked, whether Eskom has been able to harvest the potential efficiency gains that should have been possible from the application of new technology?

These insights provoke the question of whether Eskom has operated within a governance and regulatory environment that has provided sufficient incentives for improved performance. Low price, publicly owned utilities may not appear to require independent regulation or restructuring. However, this case study of Eskom in South Africa demonstrates the importance of a thorough historical understanding of utility performance in order to expose possible inefficiencies. The test for new and re-regulated electricity markets is whether they can encourage efficient investment and operational behaviour to secure electricity supply at the lowest possible cost. 


\section{Introduction}

Eskom, the publicly owned, vertically integrated electricity utility in South Africa, ranks seventh globally in terms of electricity sales. It also generates amongst the lowest priced electricity in the world. But does the fact that Eskom's prices and costs are low mean that it is also among the most efficient of electricity utilities? And, if its prices and costs are low, what is the rationale for restructuring or re-regulating Eskom?

In this paper, we describe and analyse the electricity industry in South Africa in terms of its historical investment and operational record. We examine the main elements that contribute to the cost of electricity and how these have changed over time. We conclude by arguing the case for restructuring and re-regulation in order to maximize efficiency gains in the future.

\section{Eskom's historical background}

The electricity industry in South Africa was spurred by the development of diamond and gold mining. K imberly, the site of the first large diamond mine, had electric street lights in 1882 (before London) and during the 1890s most of South Africa's major cities were reticulated. A number of independent power companies were established. For example, the VFP (Victoria Falls Power Company $L$ td) was registered in 1906 with the vision of harnessing the hydro-electric potential of the Victoria Falls to meet the demand for electricity around Johannesburg and Southern Rhodesia (Zimbabwe). Technical and financial constraints resulted in the company focusing on coal-fired power stations, which in time became the dominant electricity generator in the region.

By the early 1920s, the Government of South Africa was concerned about the lack of standardization in the power industry and the need to expand capacity to support the electrification of the railways and accelerated industrialization. London-based consultants, $M$ erz and M CL ellan, were commissioned to examine the 'general question of electricity supply' in South A frica. They recommended the need to have a central controlling authority to oversee and coordinate the development of the electricity industry. The government responded with the Electricity Act of 1922, which made the provision for the establishment of the publicly owned ESCOM (Electricity Supply Commission). ESCOM 's primary goal was to establish new electricity undertakings in cooperation with the existing generators to ensure a 
cheap and abundant supply of electricity (Steyn 2001). At the same time the ECB (Electricity Control Board) was formed to issue licences and regulate electricity prices of ESCOM and private undertakings. M unicipalities were not obliged to apply for licences. However, if municipalities wished to build new generating capacity, they had to seek the permission of the Provincial Administrators who, in turn, had to consult ESCOM. The consequence was that ESCOM began to build or finance most new power stations. It took over the VFP and T ransvaal Power Company in 1948. Today it accounts for the bulk of the generating capacity in South Africa (Steyn 1994 and 2001, Eberhard 2003).

ESCOM sought to reap economies of scale and built larger and larger coal-fired stations as South Africa has only modest hydro-electricity and gas resources. Coal, on the other hand, is abundant and is mined at low cost. Following the oil price shocks of the 1970s, diesel and oil-fired generators of municipalities were uncompetitive and they began to rely more and more on ESCOM. The national high-voltage transmission grid was also interconnected at this time. Annual growth in peak demand between 1972 and 1982 ranged between 6\% and 16\%. ESCOM engineers and planners were concerned that there would be power shortages and even ordered more power stations to be built. T heir power forecasting methods relied on extending past growth trends into the future and also on the optimistic economic growth rate. The consequence was an overestimation of demand, over-building of generation plant, and large price increases. D isquiet among stakeholders led to government appointing the DeVilliers Commission in 1983. T he Commission was critical of ESCOM 's governance, management, forecasting methods, investment decisions, and accounting (Eberhard 2003).

ESCOM underwent major organizational and institutional changes in 1985 following the implementation of the Commission's recommendations. N ew Electricity and Eskom Acts were passed in 1987. ESCOM was renamed as 'Eskom' and was reconfigured with a new two-tier governance structure modelled broadly on the German corporate governance system. A fulltime executive management board now reported to an Electricity Council comprising representatives of major electricity consumers, municipal distributors, and government representatives, all appointed by the $M$ inister of $M$ inerals and Energy. The drafters of the new Electricity Act, who included members of 
ESCOM's legal department, inserted a clause that exempted E skom from the need to have a licence issued by the Electricity Control Board and thus from having its prices regulated. E ffectively, the Act relied on the consumer-dominated Electricity Council to control prices subject to government approval. The new management also had to re-establish Eskom's credibility and reputation with the government and its customers (Eberhard 2003).

In the period following 1987, Eskom's management and operations were increasingly subject to commercial imperatives. The C apital D evelopment F und was abolished and Eskom's old fund accounting system was replaced with standard business accounting conventions. The principle of operating at 'neither a profit nor loss' was replaced by the need to 'provide the system by which the electricity needs of the consumer may be satisfied in the most cost-effective manner, subject to resource constraints and the national interest' (Eskom 1987). A number of initiatives were taken to deal with the excess generation capacity. Eskom postponed the construction of some power plants, increased the interval between the service dates of units, and mothballed and decommissioned old and inefficient power plants. No new power stations have been ordered by Eskom since 1985, although the plant ordered at that time has been commissioned later at rescheduled dates.

In the 1990s, further changes were fuelled by the democratic revolution that marked the end of the apartheid era in South Africa. A massive electrification programme was initiated and the proportion of the population with access to electricity increased from one-third to over two-thirds. A N ational Electrification Forum, comprising all interested stakeholders, recommended the rationalization of the distribution sector (too many local authority utilities are inefficient and cash-strapped). The Forum also recommended the conversion of the Electricity Control Board into a new NER ( $N$ ational Electricity Regulator) with powers to regulate the entire industry. The Electricity Act was amended and the NER was established in 1995.

$T$ he early redistributive policies of the new South A frican government embodied in its election manifesto (the Reconstruction and Development Programme) were soon accompanied by a self-imposed structural adjustment programme (named Growth, Employment and Redistribution Policy). The new emphasis was increasingly on macro-economic stability, fiscal 
conservatism, and the progressive restructuring and privatization of state-owned enterprises. An E nergy Policy Paper was published in 1998. It set out a vision for the electricity industry which included the possibility of unbundling, competition, customer choice, and private participation in the electricity industry. In 2000, the D epartment of Public Enterprises published A Policy F ramework: an accelerated agenda towards the restructuring of state owned enterprises, which further emphasized a 'managed liberalization' process.

The Eskom Conversion Bill of 2001 replaced the old Eskom Act of 1987 with subsequent amendments. Eskom was converted into a public company (named Eskom Holdings $L t d$ ) with its share capital held by the state. It now paid taxes and dividends. A memorandum to the Bill described its purpose as bringing about more efficiency and competitiveness in the running of Eskom, exposing Eskom to global trends and ensuring that Eskom is run in terms of a protocol on cooperative governance. One consequence of the corporatization of Eskom is that the capital subsidies for the connection of low-income consumers are no longer funded internally by Eskom, but derive from fiscal allocations to a national electrification fund.

The government has stated its intention to unbundle transmission and guarantee third-party access, to sell 30\% of Eskom's generation, and to introduce competition through a multi-market (comprising bilateral contracts and a voluntary spot market), with a choice for large customers (>100 G Wh per annum). H owever, to date there has been no unbundling or privatization and there is no competition in the electricity supply industry in South Africa. It is still not clear whether there are strong enough political drivers for reform that will cause initial policy pronouncement to be translated into pragmatic reform actions.

\section{The existing South African electricity supply industry}

The South African ESI (electricity supply industry) (Figure 1) remains dominated by Eskom. It supplies about $96 \%$ of South Africa's electricity requirements ( $F$ igure 2 ) which equals more than half of the electricity generated on the African continent. Eskom owns and controls the high voltage transmission grid and supplies about $60 \%$ of electricity directly to customers. The remainder of electricity distribution is undertaken by about 177 local authorities. They buy bulk-supplies of electricity from 


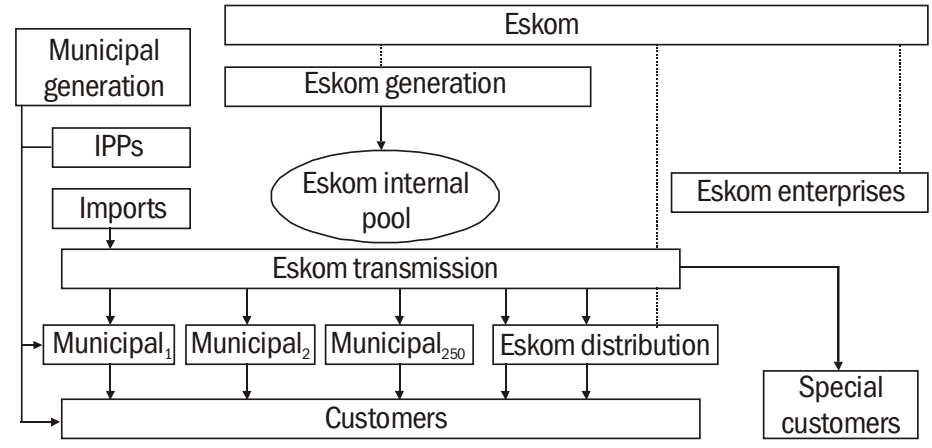

IPPs - independent power producers

Figure 1 Structure of the electricity supply industry in South Africa



SAPP - South African power pool

Figure 2 Energy flows in the Electricity Supply Industry in South Africa 2000 Source NER (2000)

Eskom, with some also generating small amounts in their areas of jurisdiction. A few industries have private generation facilities for their own use.

$\mathrm{N}$ inety-one per cent of electricity is generated from coal, nuclear energy accounts for $6.5 \%$, while bagasse, hydro, and emergency gas turbines make up the remaining $2.5 \%$. Total generating capacity in South Africa in 2000 was 43.1 GW (gigawatt) of which Eskom owns $39.9 \mathrm{GW}$ most of which is 
available for generating electricity for sale. Some capacity was mothballed and the total net operating capacity amounted to $35.3 \mathrm{GW}$. Peak demand on the system was 32 GW in 2003. Eskom has 24 power stations, of which 10 large coal-fired stations dominate-most of them comprise six $600-\mathrm{M} \mathrm{W}$ units and are situated on coal mines in the north-east of South Africa. South Africa's only nuclear station is at K oeberg, 30 kilometres north of Cape Town, and is owned and operated by Eskom. There is modest hydro-capacity generation on the O range River, located on two dams, and there are two pumped storage schemes which play a critical role in meeting peak demand, as well as in system balancing and control (Eskom 2001, NER 2001).

Eskom makes most of its profits from the sale of electricity to its large mining and industrial customers and in bulk sales to municipalities. These three customer categories account for $82 \%$ of its revenue and $89 \%$ of its electricity sales. The average selling price in 2000 to industrial customers was 1.6 cents $/ \mathrm{kW} \mathrm{h}^{2}$ and for residential customers was 3.7 cents/kWh (E skom 2000).

Tariffs for rural and low-income residential customers are cross-subsidized from industrial tariffs and surpluses earned on sales to municipalities. The large municipalities, in turn, make an additional profit from reselling Eskom electricity, which enable them to subsidize property rates and to finance other municipal services. However, many of the smaller municipalities face debt, non-payment by a substantial proportion of their lowincome consumers, inefficient operations, and lack of technical and managerial capacity.

Electricity demand growth in South A frica is primarily a function of the GDP (gross domestic product) plus new investments in energy-intensive mining and minerals beneficiation projects (such as aluminium and steel) (Figure 3). Electricity sales slowed down in 1991, 1992, and 1998 when the economic growth declined. Generally, sales in electricity consumption increased at an average rate of $4.9 \%$ from 1980 to 1990 and $2.7 \%$ from 1991 to 2001.

In broad terms, the ESI has supported economic development through the provision of low-cost and reliable supply of electricity. In recent years, it has also contributed to improving social equity by increasing access and subsidizing supplies to the poor. However, there are a number of problems and challenges

${ }^{2}$ Assuming an exchange rate of 1 dollar $=7.5$ rand 


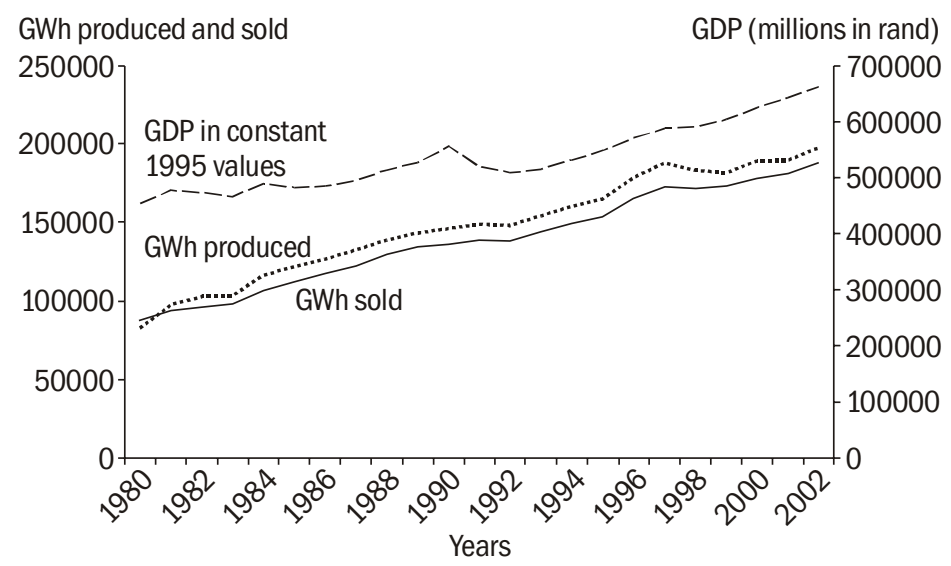

GDP - gross domestic product

Figure 3 Production and sale of electricity by Eskom and South Africa's gross domestic product

Sources Eskom Annual Reports (1980-2002); Statistical Yearbooks (1985-96) and IMF (2003, pp. 876; 2000, pp. 890)

that are driving changes. These include the need to improve the performance of the distribution industry; the need to create a competitive environment for new investment in generation capacity; and to unlock the economic value in the industry, including widening of economic participation, particularly to previously disenfranchized South Africans. But whether these are strong enough political drivers for change remains to be seen.

\section{Cost, price, and income trends}

International comparison of electricity prices

A comparison of Eskom's electricity prices with available data from selected countries shows Eskom's household and industrial tariffs to be among the cheapest in the world (Figures 4 and 5).

Do Eskom's prices cover costs?

E skom's costs have generally been covered by income. Figures 6 and 7 show that prices have been set at levels that have provided sufficient income to cover operating expenses, capital charges, as well as a positive return on capital and equity. $\mathrm{N}$ et operating income (before interest and tax) increased substantially in the early 1980 s as prices increased to fund new investment. $N$ et income (after interest and tax) has cycled in a band between 2 billion rand and 4 billion rand (in real 2000 values). Eskom has earned 


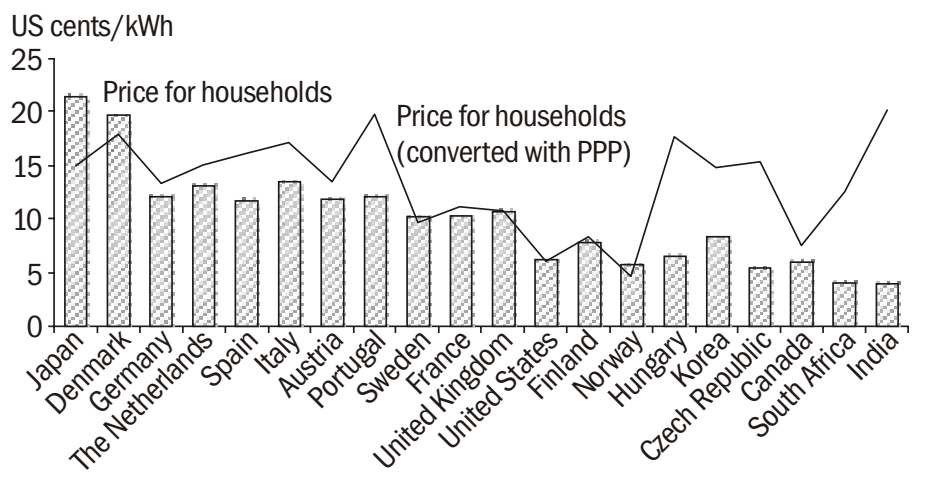

PPP - purchasing power parity

Figure 4 Household prices in selected countries in 2000

Sources IEA (2001) and EIA (2003)



PPP - purchasing power parity

Figure 5 Industrial prices in selected countries in 2000

Sources IEA (2001) and EIA (2003)

a before tax return on assets of between $8 \%-12 \%$ over the past two decades.

Eskom's net income is a function not only of its cost structure but also of the prices that it is able to charge. Eskom has been an effective monopoly and has proposed annual price increases that cover its costs. T he regulatory regime has been fairly light (indeed between 1987 and 1995, E skom was not subject to any formal regulation). In broad terms, price increases had to be politically acceptable. As its interest burden declined in the 1990s, Eskom offered a voluntary pricing compact with the 


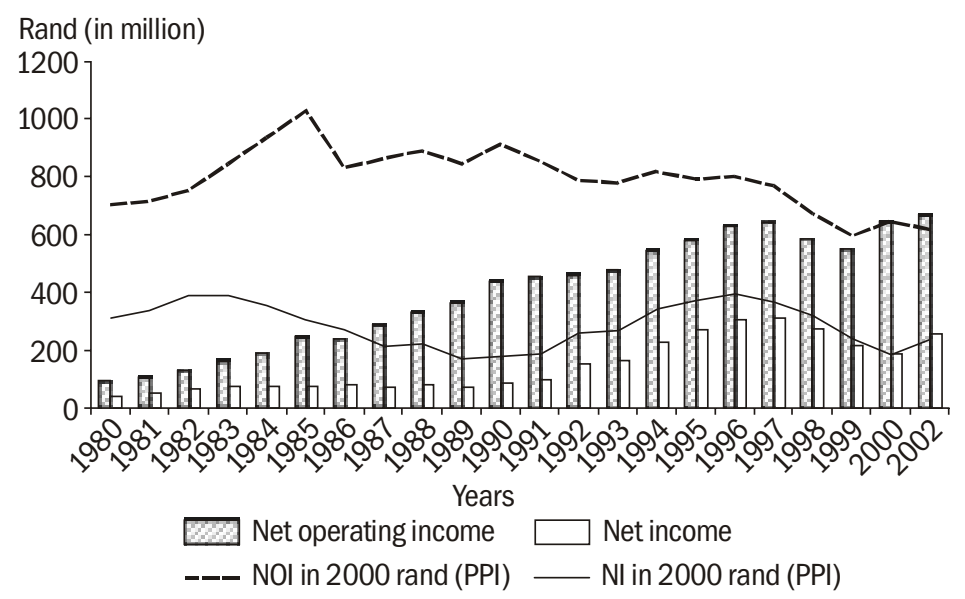

PPI - producer price index

Figure 6 Net operating income and net income from 1980 to 2001

Source Eskom Annual Reports (1980-2001)

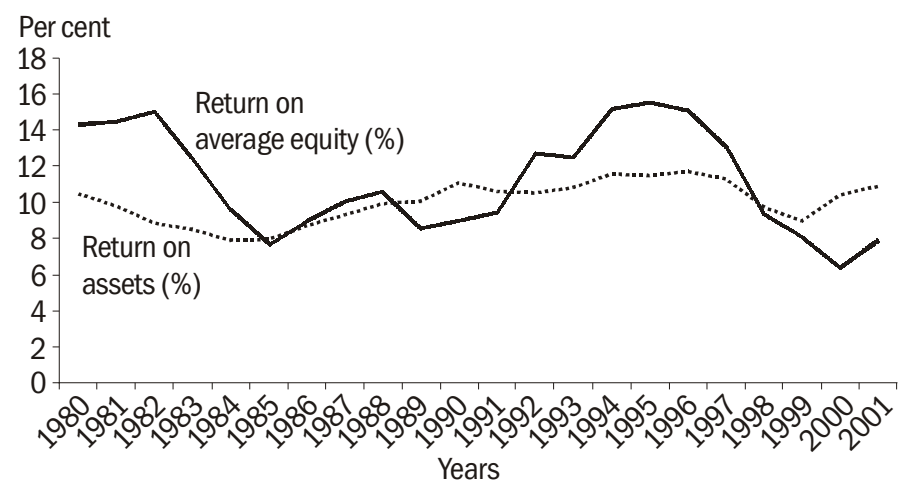

Figure 7 Eskom's return on assets and return on equity from 1980 to 2001 Source Eskom Annual Reports (1980-2001)

government to reduce the price of electricity in real terms by about a fifth. Eskom, of its own accord, told the government that it was prepared to lower the price of electricity by about a fifth over a number of years. H owever, in the past three years, Eskom has motivated for price increases above inflation, arguing that it has to fund new investment. The past three years have also seen the first serious attempt to regulate E skom and the NER has determined price increases at lower levels than requested by Eskom. 


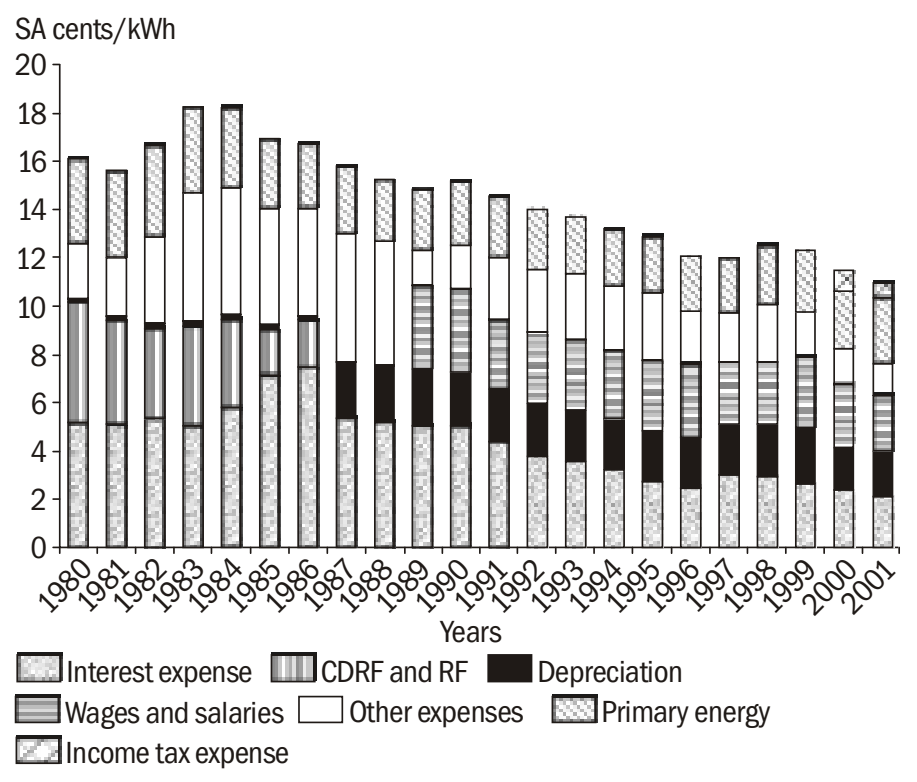

Figure 8 Eskom's electricity cost components (real year 2000 values)

Sources Eskom Annual Reports (1980-2001) and Statistical Yearbooks (1985-2001)

\section{Eskom's cost components}

Eskom's costs comprise primary energy, salaries, operating and maintenance, depreciation, interest charges, and income tax. Figure 8 shows the proportional contribution of each cost component in the electricity price from 1980 to 2001 expressed in real (2000) values. $^{3}$ G enerally, from 1980 to 1986 more than half of Eskom's costs were capital related. ${ }^{4}$ Subsequently, there was a decline in capital-related costs that has brought about a significant reduction in the price of electricity (about 3.2\% per annum on average).

\section{Analysis of factors contributing to Eskom's low cost Primary energy (coal)}

M ost of Eskom's electricity is produced from coal. Primary energy comprises just over a quarter of the cost of each unit of electricity. The price Eskom pays for coal is low compared to international coal prices. This is primarily because power sta-

\footnotetext{
$31 \mathrm{U}$ S cent $=7.5$ SA cents

${ }^{4}$ Includes interest expenditures, (capital development and reserve fund) and RF (redemption fund).
} 
Table 1 Steam and coal prices for electricity generation in dollar/tonne

\begin{tabular}{lc}
\hline Country & Prices in 2000 \\
\hline France & 35.50 \\
Germany & 42.40 \\
South Africa* & 5.87 \\
United Kingdom & 44.40 \\
United States & 24.50 \\
\hline
\end{tabular}

Sources IEA (2002, 2001, 2000), EIA (2003), and *DME (2003)

tions are built adjacent to coal mines producing low cost, low calorific-value coal, ${ }^{\mathbf{5}}$ supplied on favourable long-term contracts.

\section{International comparison of coal prices}

Table 1 shows that the price of coal in South Africa is far below that in many industrialized countries.

\section{Eskom's coal supply contracts}

Of Eskom's 10 major coal-fired stations, nine have long-term coal contracts. ${ }^{6}$ Six of these long-term coal contracts are 'costplus' and three are 'fixed price'. In the cost-plus contracts, Eskom and the coal supplier jointly provided capital for the establishment of the colliery. E skom pays all the costs of operation of the colliery and the supplier is paid a net income by E skom on the basis of a ROI (return on the capital invested) by the coal supplier in the colliery. The ROI is divided into two components: a fixed and variable portion. The fixed portion is a set ROI, payable irrespective of tonnage of coal supplied, and the variable portion is based on the tonnage supplied to Eskom. The ROI is generally escalated for half the duration of the contract and is typically between $15 \%$ and $25 \%$. In the fixed-price contract, coal is supplied at a predetermined price-a base price which is escalated by means of an agreed escalation formula. There are no early termination provisions in the contracts.

Coal prices increased in 1981 and 1982 when Eskom experienced supply problems with its contracted collieries and had to buy coal from other producers (Eskom 1981, 1982) (Figure 9).

\footnotetext{
${ }^{5} \mathrm{~F}$ or example, the Lethabo power station was designed to burn bituminous coal with a caloric value of $16 \mathrm{M} \mathrm{J} / \mathrm{kg}$, which is low world standards (Eskom 1992).

${ }^{6} \mathrm{~T}$ he tenth large coal-fired power station, $\mathrm{M}$ ajuba, operates at a variable output on a small and medium-term coal contract.
} 


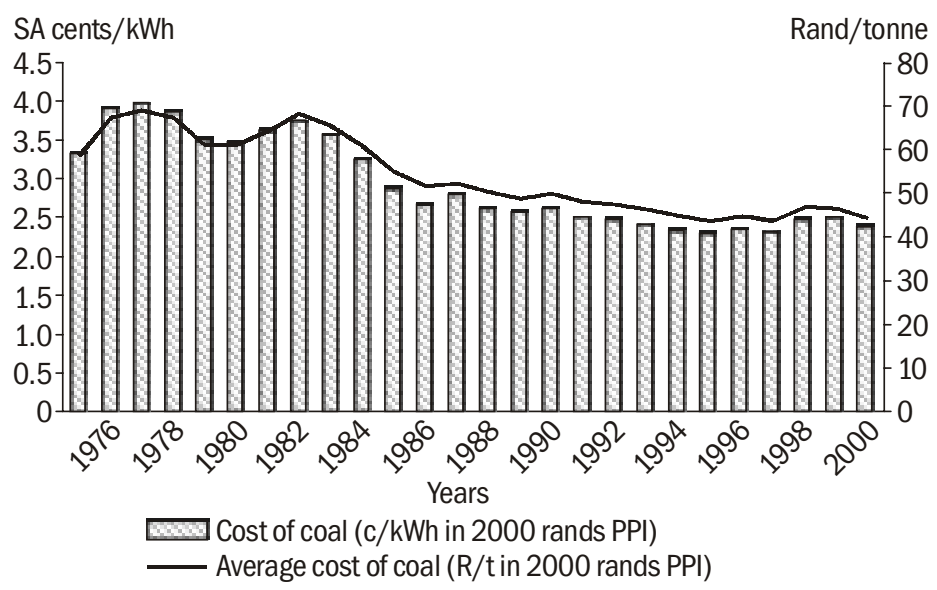

PPI - producer price index

Figure 9 Eskom coal costs (real 2000 values)

Source Eskom Annual Reports (1980-2000) and Statistical Yearbooks (1985-96)

Prices declined after 1982 as a result of more favourable coal contracts that were concluded when a new plant was commissioned. After 1995 prices were levelled off, but they are now increasing primarily as a result of the increased utilization of Eskom's more expensive plant (which requires coal to be transported by rail).

\section{Interest expenditure}

The contribution of interest charges to the electricity price has fallen over the years. In 1986, interest costs contributed to about $44 \%$ of the electricity price and it declined to $17 \%$ in 2001 (Figure 10).

\section{Reduction in capital expenditure and debt}

Eskom funded its capital expansion through commercial debt by issuing bonds on domestic and international markets. From 1980 to 1985 the real net interest-bearing debt increased at an average of $12 \%$ per annum. Interest costs halved between 1985 and 2001 and the electricity price decreased by $27 \%$ in real terms over the same period (F igure 11 ).

\section{Debt-to-equity ratio (or gearing ratio) and interest cover ratio}

The reduction in debt and interest payments is also revealed in Eskom's declining debt-to-equity ratios and in the increase in 


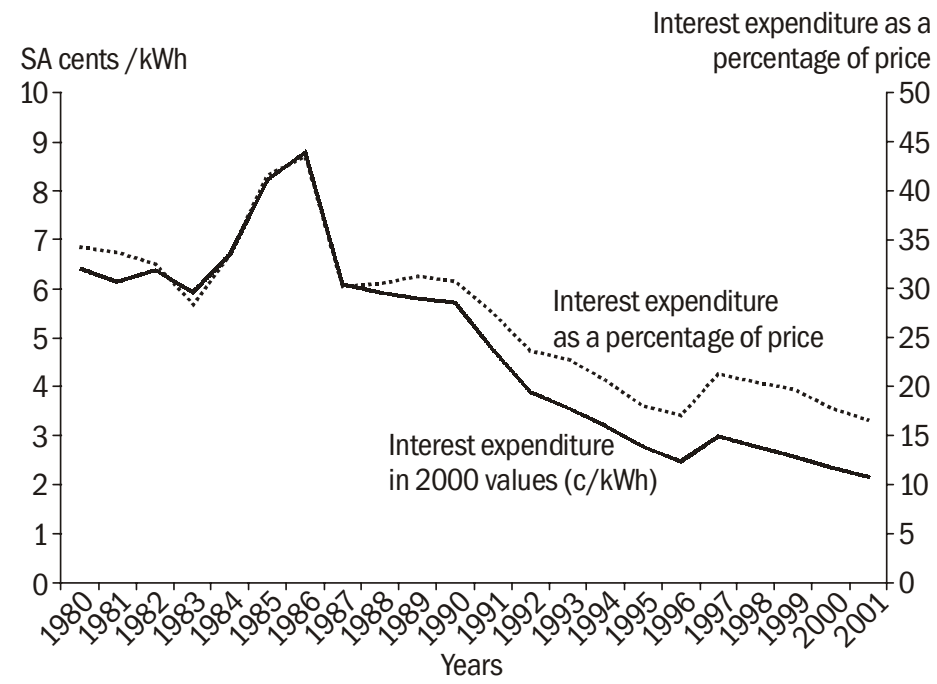

Figure 10 Interest costs per kWh (real 2000 values)

Source Eskom Annual Reports (1980-2001)



Figure 11 Net interest-bearing debt, capital expenditure, and interest costs (real 2000 values)

Source Eskom Annual Reports (1980-2001) 


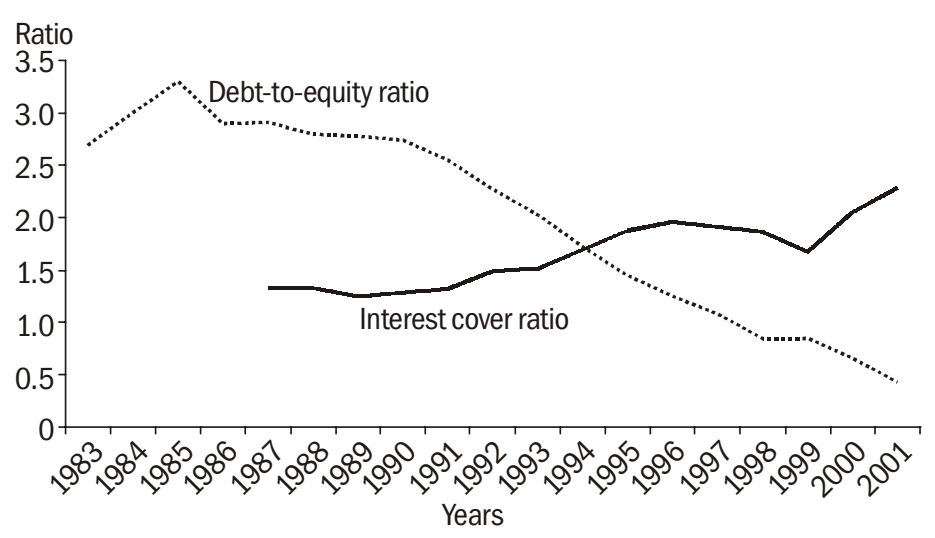

Figure 12 Debt-to-equity ratio and interest cover ratio Source Eskom Annual Reports (1983-2001)

the interest cover ratio ( $F$ igure 12 ). D ebt-to-equity ratios can be ascertained by dividing long-term liabilities by shareholders equity or total liabilities by shareholders' equity depending on the accounting policies adopted. The interest cover ratio is a ratio that shows the company's ability to honour its interest charges as they become due. It is ascertained by dividing earnings before interest and taxes (operating profit) by interest expenses. Eskom's debt-to-equity ratio increased to 3.3 in 1985 and has since then declined steadily to about 0.4 in 2003. As would be expected, Eskom's interest rate cover had improved as its debt has declined.

\section{Employment costs}

The number of E skom employees has declined from over 66000 in 1985, to 46600 in 1991, to 32800 in 2000. Figure 13 shows that the average salary per employee has increased substantially in real terms, partially off-setting the potential cost reductions that were possible from these productivity improvements.

The proportional contribution of salary costs to the electricity price has declined, as shown in Figure 14.

\section{Other factors contributing to Eskom's low prices}

There are a number of other reasons why Eskom's prices and costs may be low. Eskom was initially established as a nonprofit-making entity, and between 1923 and 2000 was liable for neither tax nor dividend payments. Eskom's electricity prices also do not fully include externalities like pollution costs. While 




PPI - producer price index

Figure 13 Wages and salaries and total employees

Source Eskom Annual Reports (1980-2001)



Figure 14 Proportional contribution of wages and salaries to electricity price Source Eskom Annual Reports (1980-2001)

electrostatic precipitators and bag filters reduce particulate emissions, Eskom power stations do not have flue gas desulphurization which is common in coal-fired plants in industrialized countries. Finally, Eskom's operational and technical performance may also contribute to low costs. This is examined in more detail below.

\section{Technical performance}

\section{Generation load factor}

The generation load factor is the ratio between the energy that a power plant has produced during a period considered and the 


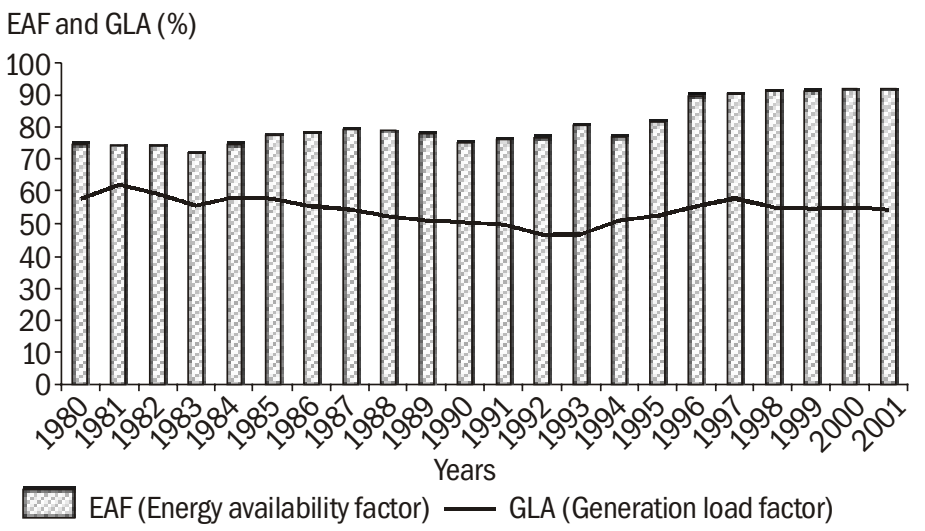

Figure 15 Average energy availability factor and generation load factor of Eskom Sources Eskom Annual Reports (1980-2001) and Statistical Yearbooks (1985-96)

energy that it could have produced at maximum capacity under continuous operation during the same period. Generation load factors are appropriate for the determination of operational performances of power plants that are exclusively meant for base load, but perhaps give a misleading picture when a peaking plant is also included. Eskom's average generation load factor has not improved over the years, partly because of overcapacity and also because of the increased 'peakiness' of the power demand profile.

The EAF (energy availability factor) is the percentage of maximum energy generation that a plant is capable of supplying to the electrical grid, limited only by planned and unplanned outages. EAF improved substantially in the early 1990s and remains at internationally comparable levels (F igure 15 ).

\section{Overall thermal efficiency}

Overall thermal efficiency 'measures the success with which the heat energy in the fuel is converted to electrical energy in the generator' (Eskom 1990). Thermal efficiency can be improved by increasing steam pressures and temperatures. An increase in thermal efficiency helps the utility to reduce the amount of coal required to produce $1-\mathrm{kWh}$ of electricity, which would subsequently reduce electricity price.

Figure 16 shows Eskom's thermal efficiency improved substantially during the 1980s as a new, larger, and more modern generation plant was commissioned. The challenge in the 1990s was to maintain this performance (though not always successfully). 


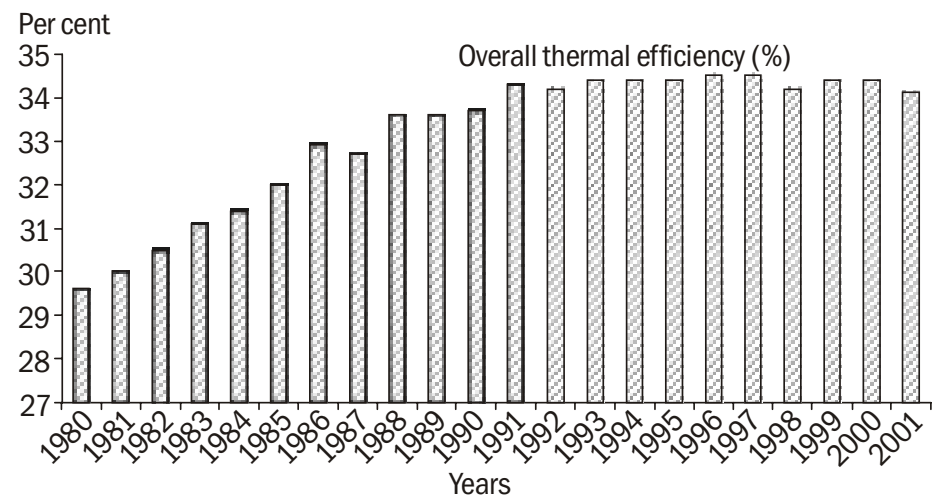

Figure 16 Overall thermal efficiency (1980-2001)

Sources Eskom Annual Reports and Statistical Yearbooks (various years)

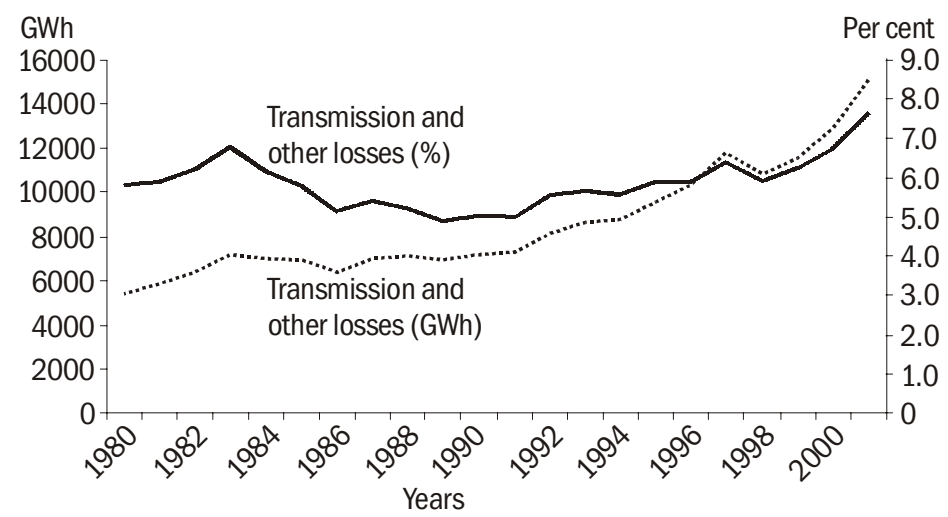

Figure 17 Transmission and distribution losses*

*Transmission and distribution losses have been calculated from the difference between electricity generated and sent out, and electricity sold.

Sources Eskom Annual Reports (1980-2001) and Statistical Yearbooks (1985-1996)

\section{Transmission and distribution losses}

Transmission and distribution losses result when electricity sold is lesser in comparison to electricity generated and transmitted (Eskom 2001), including both technical and non-technical losses due to theft and non-payment. Figure 17 shows that transmission and distribution losses have been increasing particularly from the early 1990s to 2001. This was a time when Eskom was directly involved in large-scale electrification of households which in turn led to an increase in its distribution losses. 


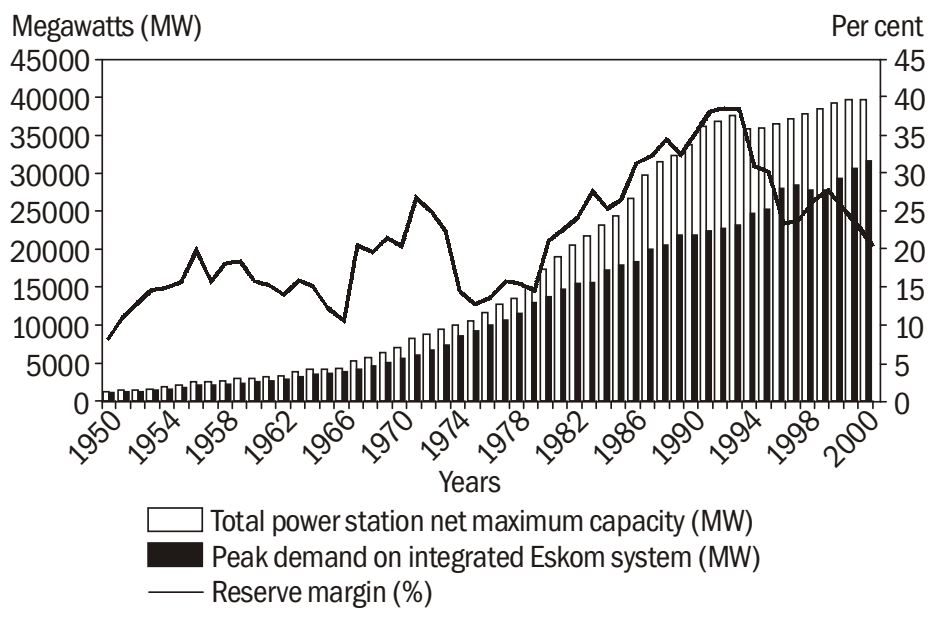

Figure 18 Net maximum capacity, peak demand, and reserve margin Sources Eskom Annual Reports (1980-2002) and Statistical Yearbooks (1985-96)

\section{Investment performance}

Investment decisions in the power sector involve high risks. $\mathrm{N}$ ew generation capacity is capital-intensive and poor investment decisions could mean that power needs are not met. Poor decisions could also result in expensive overcapacity. Investment or allocative efficiencies can have a profound impact on costs.

\section{Capacity expansion}

Figure 18 shows the growth in generation capacity compared to power demand and the percentage of reserve margin. There appears to be cyclical investment cycles of increased overcapacity followed by periods when investment slows down. T he sustained growth in new capacity between 1974 and 1993 is striking, with the reserve margin reaching a peak at $38 \%$.

Figure 19 illustrates excess capacities over and above a required $15 \%$ of reserve margin. Despite cancellation and postponement of new generation orders after the mid-1980s, excess capacity continued to grow and reached a peak of nearly $9000 \mathrm{M} \mathrm{W}$ in 1993. The annual growth in peak demand is also shown.

\section{Investment and prices}

Figure 20 again reveals the significant price hikes that were as sociated with the investment cycle, particularly the huge expansion of generation capacity in the late 1970s and 1980s. Figure 20 


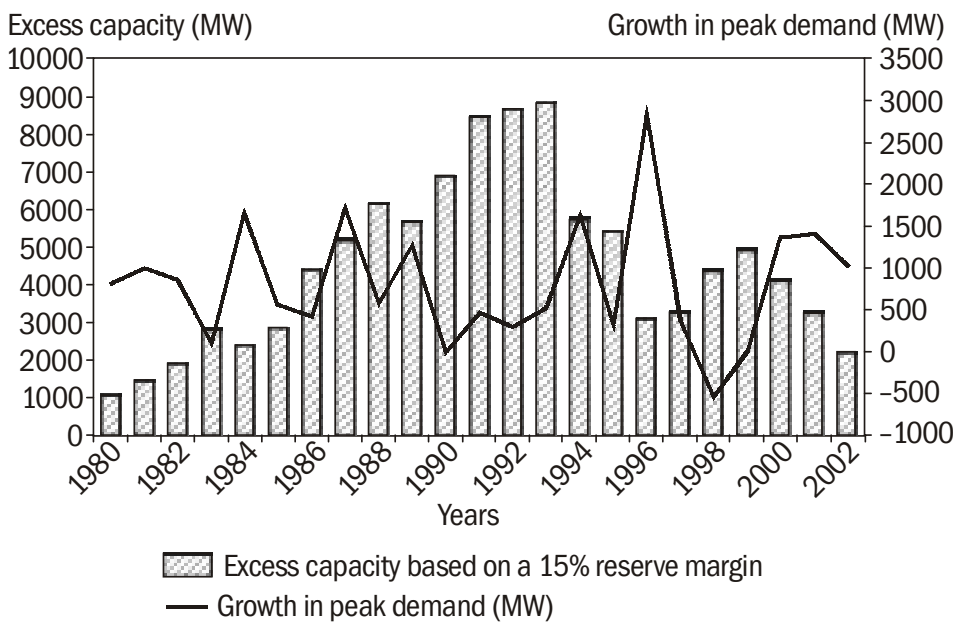

Figure 19 Excess capacities and growth in peak demand

Sources Eskom Annual Reports and Statistical Yearbooks (various years)

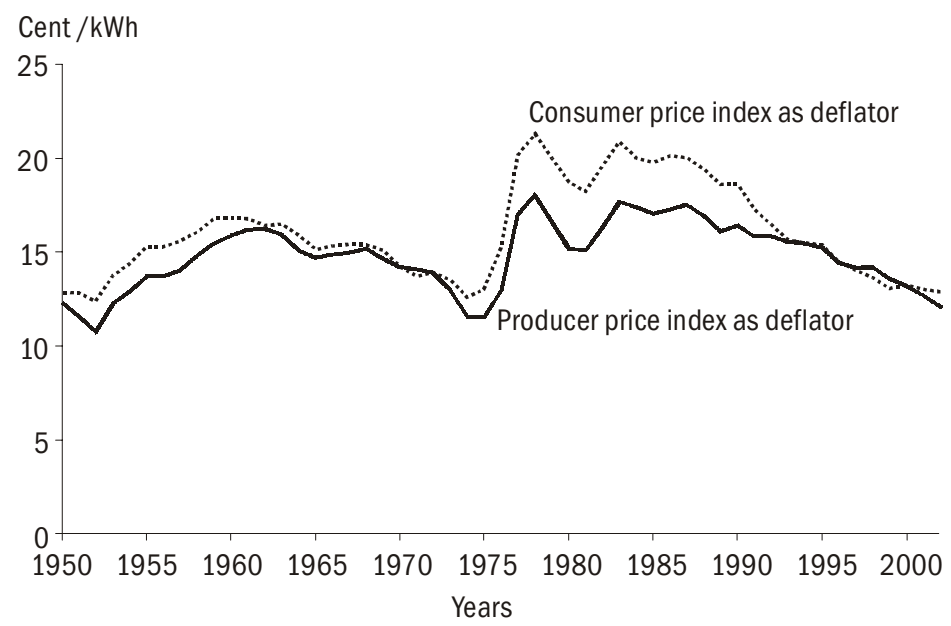

Figure 20 Long-term price performance

Source Eskom's presentation to NER (2003)

also demonstrates that Eskom's electricity price today is no lower, in real terms, than it was in the early 1950s and 1970s. Evidently the economies of scale, and improved thermal efficiencies, associated with new generation plant, have not worked their way through to a long-term decline in the electricity price. 


\section{Conclusion}

Eskom's electricity prices are clearly low by international standards. The above analysis has shown that prices are low primarily because Eskom has not had to invest in new generation plant for many years. M uch of the debt it incurred during the large expansion programme in the 1970s and 1980s has been amortized. I ts debt-to-equity ratio has been reduced substantially. Accordingly, the contribution of finance and interest charges to the cost of producing electricity are very low.

Eskom's short-run marginal costs are also low, primarily because its primary energy costs are well below international levels. Eskom power stations are situated adjacent to low-cost coal mines. F urther reasons for Eskom's low costs are the absence of flue gas desulphurization and the fact that, in previous years, Eskom was not liable to pay tax or dividends.

Labour productivity (number of employees per electricity output) has substantially improved since the mid-1980s, although higher salary levels have largely cancelled out these gains. Technical performance has improved in a number of areas. N ew generation plant enabled improved thermal efficiencies-that is less coal is required to produce a unit of electricity. Plant availability improved in the early 1990s, but has declined in recent years. Technical and non-technical losses on the distribution system have worsened through the 1990s.

Eskom's historical investment record has been poor and the above analysis indicates the extent of misallocation of capital resources that resulted in massively wasteful overcapacity in generation plants. The impact on prices has been profound as a result of this. Eskom has not always had competitive prices. In real terms, they were nearly double the current levels in the 1970 s and 1980s, and will have to rise in the future as capacity runs out and new investments have to be made in generation.

The long-term price trend reveals that current electricity prices, in real terms, are at the same level as the early 1950s and early 1970s. T he question then has to be asked whether Eskom has been able to harvest the potential efficiency gains that should have been possible from the application of new technology?

The implication of the above analysis is that a snapshot view of Eskom's current low prices does not provide any real indication of its efficiency. However, an examination of historical trends reveals important insights. It is clear that there have been major investment inefficiencies. It is also clear that over the long 
term, we have not seen consistent downward pressure on operational costs that would have been expected from the employment of new technology and improved productive efficiencies.

T hese insights provoke the question whether Eskom has operated within a governance and regulatory environment that has provided sufficient incentives for improved performance. When these questions are raised within policy debates regarding the possible restructuring of Eskom, the rejoinder is often: 'if it ain't broke don't fix it!' H owever our analysis has shown that there are serious shortcomings in the way investment risks have been managed, with profound long-term cost and price implications. In a monopolistic model, risks and costs of poor investment decision are simply passed on to consumers. Steyn (2001) has demonstrated that there are a number of inherent characteristics of monopoly institutions that make this quite likely. There is a sound basis for serious consideration of a new institutional model for the electricity industry in South Africa: one that will provide a more appropriate apportioning of investment risk. Indeed, work has begun on designing a competitive electricity market for South Africa (E berhard 2001).

The effectiveness of regulation also has to be questioned. Although Eskom's marginal costs are low by international standards, we have shown that low coal costs are one of the primary reasons. There is little hard evidence on how Eskom's productive efficiencies compare internationally. Regulation of Eskom has historically been quite light. However, in recent years the NER has been instituting a more rigorous and transparent regulatory methodology and there is some indication that there is room for further efficiency improvements.

Low price, publicly owned utilities may not appear to require independent regulation or restructuring. This case study of Eskom in South Africa demonstrates the importance of a thorough historical understanding of utility performance in order to expose possible inefficiencies. The test for new, re-regulated electricity markets is whether they can encourage efficient investment behaviour and operational performance to secure electricity supply at the lowest possible cost.

\section{Bibliography}

De Villiers W J. 1984

Report of the Commission of Inquiry into the supply of electricity in the Republic of South Africa

Pretoria: Government Printer 
DME (D epartment of M inerals and Energy). 1998

White Paper on Energy Policy for Republic of South Africa

Pretoria: Department of $\mathrm{M}$ inerals and Energy

DME (D epartment of M inerals and Energy). 2003

Production and sale of coal, Table 19

[A vailable at www.dme.gov.za/publications/pdf/stats/minerals/tables tb/19.pdf (accessed on 24 July 2003)]

Eberhard A. 2000

Competition and Regulation in the Electricity Supply Industry in South Africa. A paper for the Competition Commission South Africa Cape Town: U niversity of C ape Town

Eberhard A. 2001

Competition and Regulation in the Electricity Supply Industry in South Africa

[A paper presented to the Trade and Industrial Policy Strategies Annual F orum, Pretoria]

Cape Town: Graduate School of Business, University of Cape Town.

Eberhard A. 2003

The Political, Economic, Institutional and Legal Dimensions of Electricity Supply Industry Reform in South Africa

[Working Paper Series]

Stanford, USA: Centre for Environmental Science and Policy, Stanford U niversity

EIA (Energy Information Administration). 2003

Monthly review, July 2003

[A vailable at www.eia.doe.gov/emeu/international/stmforelec.html. (accessed on 11 September 2003)]

Eskom. 1981

Eskom Annual Report

Johannesburg: Eskom

Eskom. 1982

Eskom Annual Report

Johannesburg: Eskom

Eskom. 1987

Eskom Annual Report

Johannesburg: Eskom

Eskom. 1989

Koeberg nuclear power station: General information brochure

C ape Town: Eskom

Eskom. 1990

Eskom Annual Report, pp.19

Johannesburg: Eskom 
Eskom. 1992

Eskom Annual Report, pp. 24

Johannesburg: Eskom

Eskom. 2000

Eskom Annual Report

Johannesburg: Eskom

Eskom. 2001

Eskom Annual Report, pp.124

Johannesburg: Eskom

Eskom. 2002

E skom tariffs and charges for January to June $\mathbf{2 0 0 2}$

[A vailable at www.eskom.co.za/tariffs (accessed on 20 September 2002)]

H eap J. 1992

Productivity Management: a fresh approach

London: Cassell Educational Limited

IEA (International Energy Agency). 2000

E lectricity Information 2000 with 1999 data

Paris: IEA

IEA (International Energy Agency). 2001

Quarterly statistics (Third quarter 2000)

Paris: IEA

IEA (International Energy Agency). 2002

Retail prices in selected countries in US Dollars/Unit.

[A vailable at www.iea.org/statist/keyworld2002/key2002 p_0505.htm

(accessed on 18 June 2003)]

I M F (International M onetary F und). 2000

International Financial Statistics, LIII

Washington, DC: IM F

I M F (International M onetary F und). 2003

International Financial Statistics, LVI

Washington, DC : IM F

K hatib H. 2001

Environmental performance of generation plant: electricity generation and global environmental protocols

In Performance of $G$ enerating Plant (Section 5) [A report by the World Energy

Council, O ctober 2001]

London: World Energy Council

M ahona B, Hoppe-K ilpper M, Vigoti R, Hughes E, Bertani R. 2001

Renewable energy plant

In Performance of $\mathrm{G}$ enerating Plant (Section 2) [A report by the World Energy

Council, O ctober 2001]

London: World Energy Council 
NER (N ational Electricity Regulator). 1998

\section{Lighting up South Africa}

Pretoria: NER

NER (N ational Electricity Regulator). 2000

\section{Electricity Supply Statistics for South Africa 2000}

Pretoria: NER

NER (N ational Electricity Regulator). 2001

\section{Electricity Supply Statistics for South Africa 2001}

Pretoria: NER

Spiegelberg R, K aupang B, Glorian D, Blin P. 2001

Thermal generating plant (100 $\mathrm{MW}+)$ availability and unavailability factors: 2001

In Performance of Generating Plant (Section 1); [A report by the World Energy Council, October 2001]

L ondon: World Energy Council

Statistics South Africa. 2003a

Consumer Price Index

[Available at www.statssa.gov.za/Products/Releases/C PI_H istorical/

CPIH istoricalC urrent.pdf

(accessed on $10 \mathrm{M}$ arch 2003)]

Statistics South Africa. 2003b

\section{Production Price Index}

[A vailable at www.statssa.gov.za/Products/R eleases/PPIH istorical/

PPI_H istoricalC urrent.pdf

(accessed on 11 D ecember2002)]

Steyn G. 1994

\section{Restructuring the South African Electricity Supply Industry}

Cape Town: Energy for Development Research Centre, University of Cape Town

Steyn G. 2001

Governance, Finance, and Investment: decision making and risk in the electric power sector [DPhil]

Brighton: U niversity of Sussex

World Bank. 2003

The International Comparison Programme and Purchasing Power Parities

[A vailable at www.worldbank.org/data/icp/pppdata.htm.

(accessed on 20 June 2003)] 